\title{
ギリシア古代都市メッセネにおける劇場のローマ時代客席部の 現状報告と復元試案 \\ DESCRIPTION AND TENTATIVE RECONSTRUCTION OF THE ROMAN CAVEA OF THE THEATER IN ANCIENT MESSENE
}

\author{
岩田千穂*，伊藤重 剛**
}

\section{Chiho IWATA and Juko ITO}

\begin{abstract}
Ancient Messene, Greece, was founded by Epaminondas in 369 B.C. Kumamoto University Architectural Mission to Greece has surveyed, since 2007, the architectural remains of the theater including more than a hundred blocks from walls, columns, etc., in order to reconstruct its form of Roman period. The authors analyzed remains and blocks in detail and tried to reconstruct the cavea in the last phase from the 1st to 3rd century A.D We have reached conclusion that tha cavea was separated in 3 parts with 2 diazoma. The lower and middle cavea were separated into 11 and the upper cavea into 16 .
\end{abstract}

Keywords: Ancient Greece, Roman era, Messene, Theater, Cavea, Reconstruction 古代ギリシア，ローマ時代，メッセネ，劇場，客席，復元

\section{1. 序論}

\section{1-1. 研究背景}

ギリシアのペロポネソス半島南西部にある古代都市メッセネは、 紀元前 369 年にエパミノンダスにより建設された都市である ${ }^{1)}$ 。全 長約 9m の市壁に囲まれた都市内のゆるやかな傾斜地に主要な公共 施設が建設され、都市の中心部となっている。劇場は、アゴラの北 西隅から約 $34 \mathrm{~m}$ 西にあり、自然の斜面を利用して作られている。

メッセネ考古学協会 (会長 : 元クレタ大学教授、P. テメリス氏) による劇場発掘は、1990 年台に開始され、発掘がひと段落した 2010 年以降は、現場での修復作業がおこなわれている ${ }^{2)}$

筆者ら熊本大学ギリシア古代建築調査団 ( 団長：伊藤重剛 ) は、 2007 年から 2012 年にかけて、建築班として当該劇場の建築調査を おこなっている。調查団の調査目的は、劇場の建築学的研究をおこ なうことであり、具体的な調査内容は、劇場の建築遺構や建築部材 の実測、写真撮影、そして詳細な観察記録をとることである ${ }^{3)}$ 。

\section{1-2. 既往研究および本研究の目的と位置づけ}

紙面の都合上、ギリシア劇場の既往研究に関しては詳述しないが、 個別の劇場の復元研究は各遺跡の発掘報告に見られる。一例として、 ギリシアで最も保存状態のよいエピダウロスの劇場に関する文献が 挙げられる ${ }^{4)} 。$

本稿の目的は、現地調査の成果から劇場の客席部の現状報告をお こない、調査成果をもとにローマ時代の最終段階の客席部 ${ }^{5)}$ の復元 を試みることである。テメリス氏は、劇場は、前 3 世紀ごろに最初
の建物が建設され、後 2 世紀ごろにローマ劇場に改築、後 3 世紀ご ろまでにオルケストラがアレナに改変され、後 4 世紀ごろに都市の 衰退とともに放棄されたと推定している。また、西パロドスの壁は、 ローマ時代の舞台建物が建てられた際、これに平行になるよう改変 されたとしている ${ }^{6}$ 。ただし、ローマ時代の舞台建物は、後 1 世紀 に建設されたことが吉武氏により明らかになっている7ため、劇場 全体が後 1 世紀以降にローマ劇場に改変されたと考える。本稿では、 後 1 世紀から後 3 世紀にかけての、ローマ劇場としての最終段階の 客席部の復元を試みる。

著者らと吉武氏は、これまでに本劇場のローマ時代の舞台建物の 復元案を提案している ${ }^{8)}$ 。客席部については、2011 年に同調查隊に よる復元案を発表した ${ }^{9}$ 。この時提示した復元案の問題点は、2 本 の周回通路により 3 層に分かれる客席の全層が同じ勾配で作られた ことを前提に復元をおこなったため、客席の復元勾配と階段通路の 遺構、パロドスの壁および笠木部材の勾配との間に矛盾が生じてい る点である。本稿では、この点を解決するために、各層での客席勾 配が異なる可能性もあるとして、遺構や出土部材から得られた実測 データを元に客席勾配を再考し、復元を試みるものである。

本論では、第 2 章で劇場建物全体の概要と現状を述べ、第 3 章で 客席部の遺構の現状を、第 4 章で客席に関連する出土部材の現状を 述べる。第 5 章にて、遺構と建築部材の分析をもとに客席全体の復 元を試みる。第 6 章で結論を述べる。

\footnotetext{
* 熊本大学大学院自然科学研究科 大学院生 ·修士 (工学)

** 熊本大学大学院自然科学研究科 教授. 博士 (工学)
} Graduate Student, Graduate School of Science and Technology, Kumamoto University, M. Eng.

Prof., Graduate School of Science and Technology, Kumamoto University, Dr. Eng. 


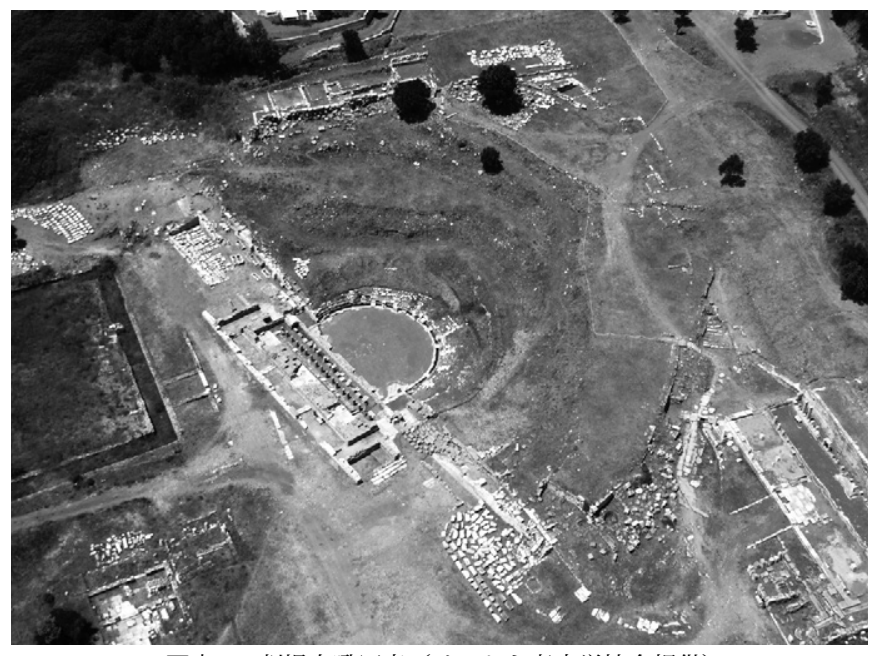

写真 1 劇場鳥瞰写真（メッセネ考古学協会提供）

2. 劇場遺構の現状 (写真 1、図 1、2)

劇場は、南北約 $90 \mathrm{~m}$ 、東西約 $100 \mathrm{~m}$ で、客席が南向きに造られて おり、その周囲は幅約 $2 \mathrm{~m}$ の石積みの後壁で支えられている。客席 の南側は、東西パロドスの壁により支えられている。

客席の南側には、東西 $46.6 \mathrm{~m}$ 、南北 $15 \mathrm{~m}$ の後 1 世紀に建設された と考えられるローマ時代の舞台建物遺構がある。舞台背景となって いたスカエナエ・フロンスには 3 つのニッチがあり、それぞれのニッ チ背後にはポストスケニオンへの出入口がある。舞台袖にも出入口 があり、ポストスケニオンと通路でつながっている。

舞台建物の東には、可動式の木造舞台背景を収納するための舞台 収納庫と思われる遺構が出土している。遺構の西端から東側の壁ま での長さが $27.55 \mathrm{~m}$ 、幅が $8.13 \mathrm{~m}$ である。この中に、溝が付けられ た石材がレール状に並べられた遺構が、東西に平行に 3 本出土した。 現在では、遺構の北側と東側の壁のみ残っている。この遺構は、ロー マ時代の舞台建物が建設される以前に使用されていたものというこ とが、両遺構の切りあい関係から判明している。

一般に、ギリシア劇場は客席と舞台建物とは構造的に分離して建 てられ、基本的に半円形より大きな扇形の客席と円形のオルケスト ラをもつ。これに対しローマ劇場は、客席と舞台建物とが構造的に 一体となり、客席やオルケストラは半円形である。また、ローマ劇 場の舞台背景となる部分は、列柱が立ち並ぶ壮麗なものであった。 当該劇場遺構には、ギリシア、ローマ劇場双方の特徵をみることが できることから、ギリシア劇場からローマ劇場へ計画変更がおこな われ、詳しい年代は不明確であるが、少なくとも 3 段階の建築段階 があったということがわかる。第 1 段階は、ギリシア劇場として創 建した段階、第 2 段階は舞台収納庫が建設された段階、第 3 段階は 後 1 世紀以降、ローマ劇場へ計画変更がおこなわれた段階である。 また、パロドスの壁の石積みが数種類あることから、前述の 3 段階 に加えさらに 1 段階あった可能性もある。

\section{3. 劇場客席部各部の現状}

\section{3-1. オルケストラ (写真 2)}

オルケストラは、円の 4 分の 1 を舞台建物が切り取る形になって いる。オルケストラの直径は、幅約 $0.5 \mathrm{~m}$ のエウリポスと呼ばれる 側溝の内側に並べられた縁石の内側で $21.6 \mathrm{~m} 、$ エウリポスまで含め

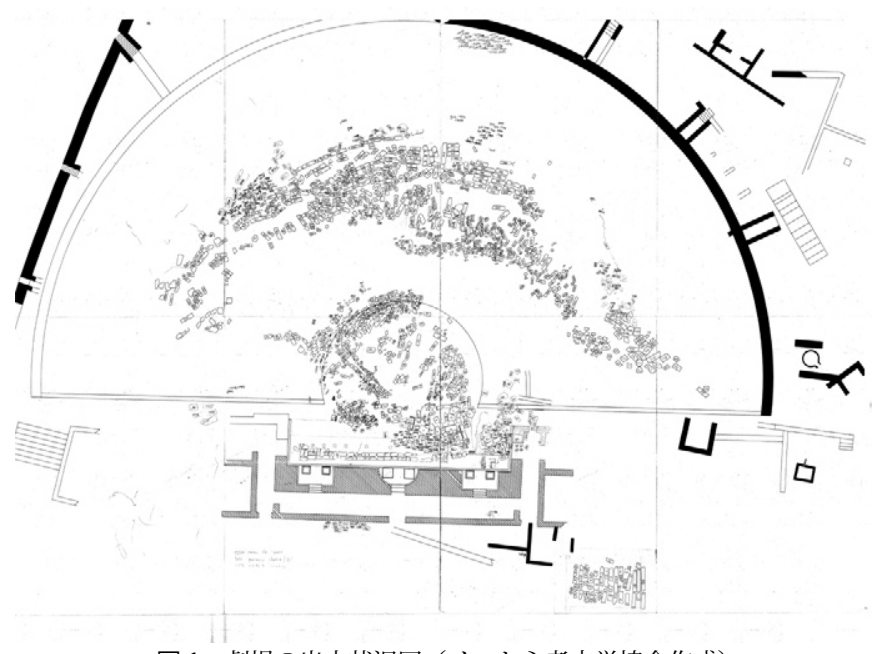

図 1 劇場の出土状況図 (メッセネ考古学協会作成)

ると $23.6 \mathrm{~m}$ である。エウリポスはポロス材 (茶色のやわらかくて粗 い石灰岩 )を並べて作られている。エウリポスの内側に並ぶ縁石は 幅 0.4 0.5m 程度の矩形の石材で、数 $\mathrm{m}$ おきに $10 \mathrm{~m}$ 角の穴が開いた 正方形の石材が配置されている。また、エウリポスの内側の縁石上 に彫刻の台座が置かれている部分が 4 箇所あり、エウリポスの外縁 に沿って置かれている部分が 1 箇所ある。階段通路がある位置には、 エウリポスの上に板石が置かれ、オルケストラから階段通路へ出入 りできるようになっている。また、階段状通路のない部分でも何箇 所かに同じような板石が置かれ、その上に貴賓席が置かれている箇 所が 2 箇所ある。ただし、彫刻の台座や貴賓席が原位置を保ってい るかは不明である。

オルケストラの床面には、ローマ時代になってから舗装されたと 考えられる赤、白、灰などの約 $0.2 \mathrm{~m}$ 角の四角い大理石板が並べら れいるのが部分的に残っている ${ }^{10)}$ 。これらの大理石板の中には、アー チ形の建築部材を再加工した板石も含まれている。オルケストラ北 東部には、2 枚の大理石板を立てて脚とし、その上に 1 枚の大理石 板を水平に載せた祭壇の跡がある。

\section{3-2. 客席}

客席自体は、ほとんど崩壊した状態で出土したが、劇場東西後壁 やオルケストラにより客席の範囲はおおまかに判明している (図 1)。 客席があったと思われる斜面の北中腹で、0.1 0.2m 角の粗石が積 まれた状態で発見された。これは、客席の基礎の一部と考えられる。

また、座席の最下段から 2、3 段程度、部分的に座席が残ってい る (写真 3)。最下段の座席は、エウリポスの外縁に接するように置 かれたポロス材の座席である。座席 2 段目以降は、石灰岩製の薄い 板材を水平と垂直に配置して座席を構成している。現在積まれてい る座席の一部は、発掘者により修復されたものである。

\section{3-3. 階段通路}

階段通路は、最下段の数段分のみ残っており、発掘時にはややゆ るんだ状態で出土したが、現在は修復され整えられている。階段通 路は合計 10 本あり、客席の最下層は 11 クネイに分割されていたこ とがわかる。また、パロドスの壁に沿った階段通路は作られていな い。階段の各部寸法は、幅が約 $0.72 \mathrm{~m}$ 、踏み面は最小 $0.290 \mathrm{~m}$ 、最大 $0.460 \mathrm{~m}$ 、蹴上は最小 $0.097 \mathrm{~m}$ 、最大 $0.220 \mathrm{~m}$ である。

通常、各階段通路の延長線はオルケストラの中心点に一致する。 

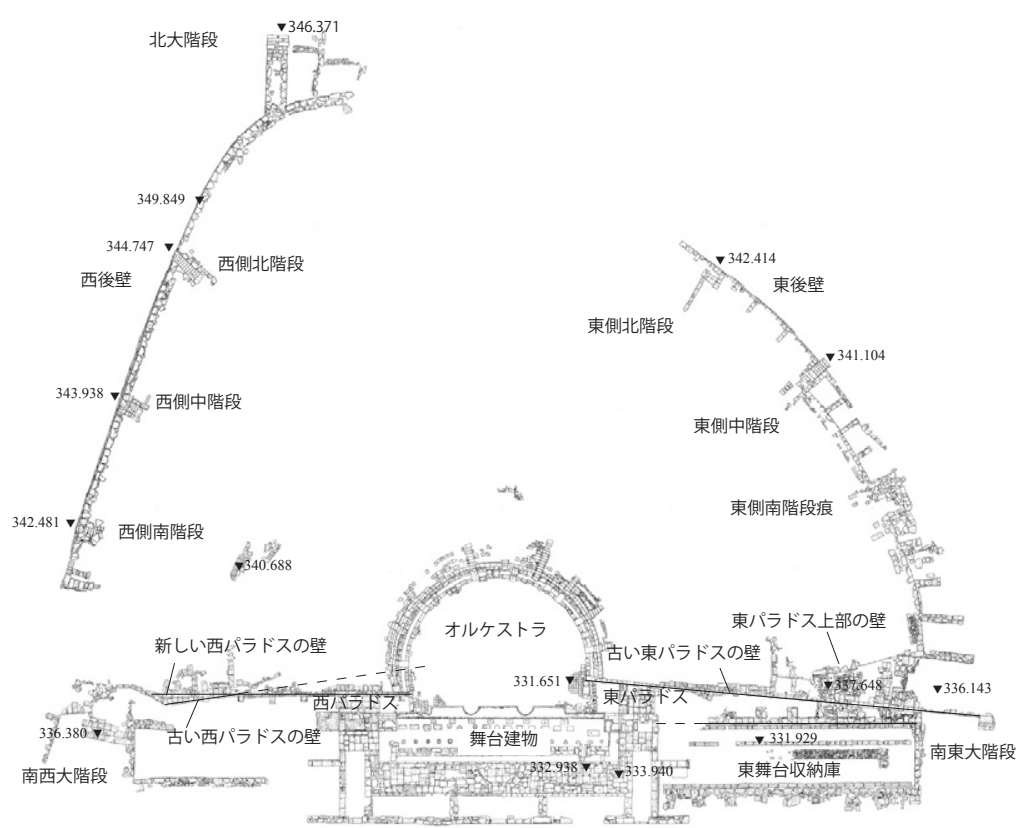

0000007

図 2 劇場全体の現状平面図

本劇場の場合、10 本の階段のうち、その延長線がオルケストラの中 心点にほぼ一致するのが東から 8 本の階段で、残る西から 2 本の階 段の延長線は、オルケストラの中心点に一致せず、舞台建物のプロ スカエニウム・ウォールの西半円形ニッチ付近へ収束する ${ }^{11 。}$

\section{3-4. 周回通路}

周回通路は、客席に沿って作られる円弧形の水平通路である。現 状でその痕跡がほとんど残っていないが、その痕跡と考えられるも のが、3 䇢所で確認される。1 䇢所目は、劇場が出土した斜面の西 中腹に出土しているポロス材と石灰岩の列である。これらは、長さ 約 $2 \mathrm{~m}$ に渡って出土しており、石灰岩材列の上にポロス材列が載る かたちとなっている。2 䇢所目は、西パロドスの壁の一部がオルケ ストラ中心から約 $31.8 \mathrm{~m}$ の地点で切れ、石灰岩製石材で舖装された 床のようなものが見えている部分である。3 箇所目は、東後壁の南 端部に設けられている斜路とその曲がり角と思われる部分である。

\section{3-5. パロドスの壁}

客席と舞台建物との間は、役者や観客が通るパロドスという通路 となり、客席側の壁は、客席を支える壁となる。メッセネの劇場の パロドスの壁は劇場の東西で出土しており、少なくとも 2 度の改変 の痕跡が見られる。

西パロドスの壁は、舞台建物の壁とほぼ平行だが、オルケストラ から西へ約 $20 \mathrm{~m}$ の地点で、下部のみが外側へ 7 度折れ曲がり突出し ており、上部のみ舞台建物と平行になるよう石材が積まれている(図 2 左下、写真 4$)$ 。扔そらく、壁の建設途中あるいは建設後に、舞台 建物と平行になるように上部のみ積み直したのだろう。壁東部は舞 台建物と平行で、 $\mathrm{L}$ 字型に整形した石灰岩材を精緻に積んで構成さ れているが、壁西部では矩形の石灰岩材のみを整層積みにして構成 されている(図3左)。また、3本のバットレスが約 $3.1 \mathrm{~m}$ 抢きに作 られている。壁西部では、下部がポロス材と一部石灰岩で構成され

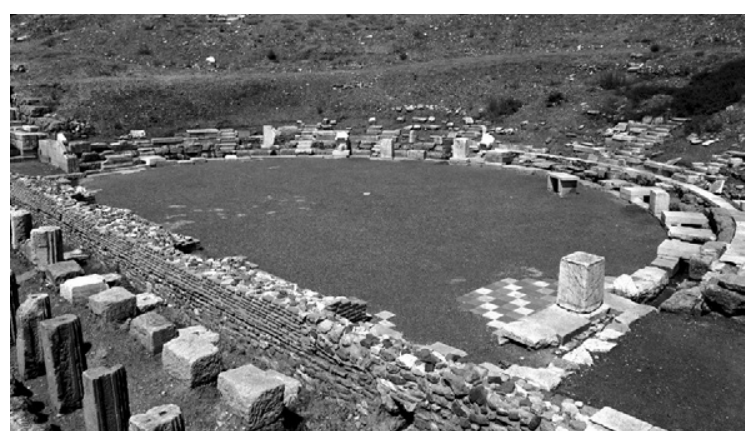

写真 2 オルケストラを南東より見る

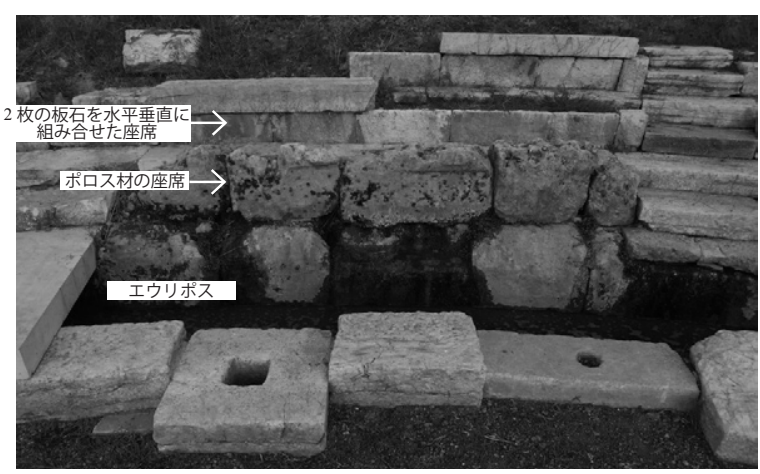

写真 3 オルケストラのエウリポスと客席 1 3 段目

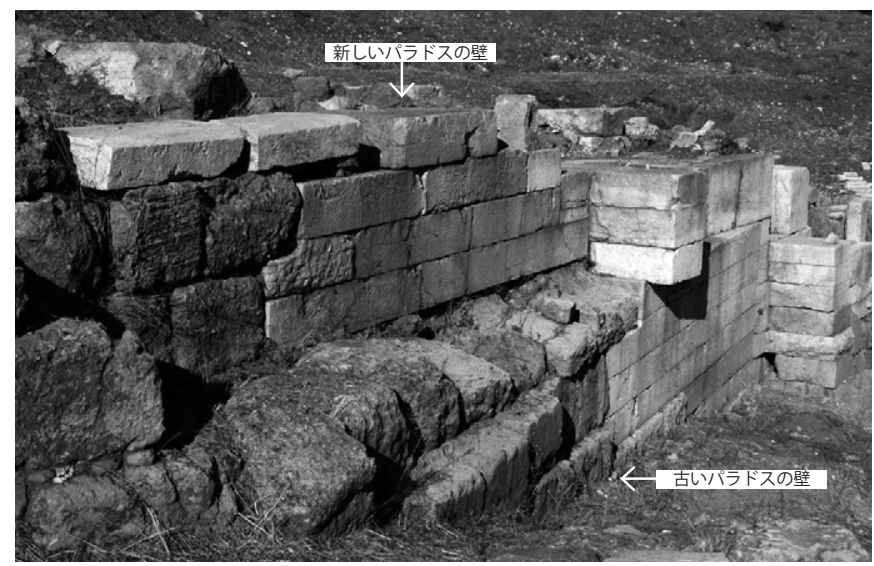

写真 4 西パラドス西部の壁下部のみが外へ折れ曲がる部分

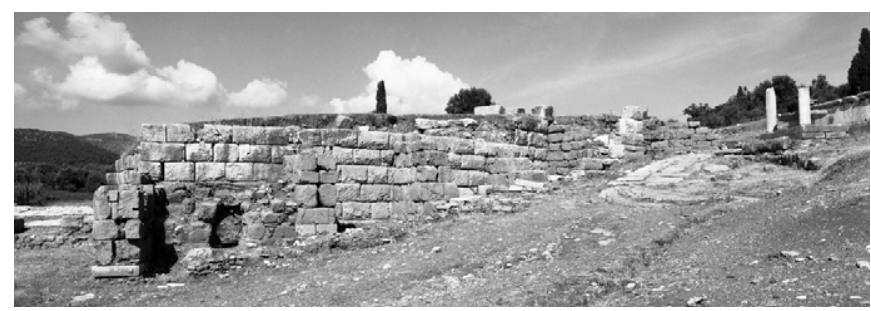

写真 5 東後壁全体を南東より見る

ており、壁東部では、石灰岩材列の内側にポロス材列がある。

一方、東パロドスの壁は、舞台建物の壁と平行でなく 5.5 度角度 をなしている (図 2 右下)。壁は、全長約 $41 \mathrm{~m}$ で、エウリポスの縁 石の位置から劇場東端部まで続いている。壁西部では、長さ 0.9 $1.2 \mathrm{~m}$ 厚さ高さともに $0.4 \sim 0.6 \mathrm{~m}$ のポロス材を整層積みにした石積 みが発見されたが、上部全体が地震などで一度に崩れたようで、横 倒しの状態で発見された。壁東部では、ポロス材列の上部に石灰岩 
が載っている。また、東パロドスの壁東端部には、東側外部からの 出入り口があり、石灰岩の板石で舗装された斜路がある。この斜路 の北側に全長約 $16 \mathrm{~m}$ の石灰岩材による壁が作られている (図 4 左 下)。東パロドスの壁のすぐ南側には、石灰岩を積んだ可動式舞台 収納庫の北壁が $26.5 \mathrm{~m}$ にわたって残っており、パロドスの壁との間 には、石材が詰められている。この壁は、舞台建物に対して 5.5 度 角度がついているポロス材の壁よりも後に作られたと考えられる。

3-6. 客席後壁と外部階段（図 4)

東西後壁は、客席部の外縁を支える厚さ約 $2 \mathrm{~m}$ の重厚な壁で、現 在までに劇場西部で長さ約 $60 \mathrm{~m}$ 、東部で長さ約 $50 \mathrm{~m}$ にわたり発掘さ れている (写真 5) が、北部に未発掘の部分が $40 \mathrm{~m}$ ほどある。壁が 最も高い位置まで残っているのは、西後壁の一部で、壁外側の地表 面からの最高高さ約 $5 \mathrm{~m}$ である。後壁の平面形は、西後壁と東後壁 北部が放物線状の形、東後壁南部が円弧をなすような形となってい る。西後壁は、ルスティカ仕上げの石灰岩を積んで構成されている。 一方、東後壁の石積みに使用された石材の仕上げは、西後壁の石材 と比べて石材表面の突出が少ない。東後壁の北方では、壁の最下部 に砕石を積み、その上に石灰岩材、さらにその上にポロス材を積ん で壁を構成しており、東後壁南方の石積みと構成が異なる (図 4 右 下)。また、東後壁南部には、3〜 $4 \mathrm{~m}$ おきにバットレスが付けられ ている。後壁各部の石材の仕上げと壁の構成から、少なくとも 1 度 改変された可能性が示唆される。

両後壁のすぐ外側には、板石で舗装された傾斜路がある。西後壁 では、排水溝の上に板石で蓋をし、幅約 $2 \mathrm{~m}$ の通用路となっている。 東後壁の外側は、劇場とその東に隣接するアルシノエの泉との間を 通りアゴラへ抜ける都市内の主要な街路となっており、一部板石の 舗装が残っている。これらの街路から客席へ出入りするための階段 が、西後壁に 4 本、東後壁に 3 本の階段が設けられている。これら のうち、西後壁の西北端に設けられた階段は、幅約 $2.6 \mathrm{~m}$ 長さ約 $9.9 \mathrm{~m}$ の大階段であり、劇場北側からの主要な出入口であったと考えられ
る。この階段を、北大階段とする。西後壁には、このほかに幅約 $1.3 \mathrm{~m}$ の階段が 3 本設けられている。これらを、北から順に西側北階 段、西側中階段、西側南階段とする。各階段間の距離は、内法で約 $15 \sim 20 \mathrm{~m}$ である。南階段と中階段の上部には持ち送りアーチが残つ ており、階段上部に屋根が架かっていたことをうかがえる。東後壁 に設けられた 3 本の階段を、北から順に東側北階段、東側中階段、 東側南階段とする。東側北階段、東側中階段は、数段残っているが、 東側南階段はその痕跡のみが発見されている。

後壁とパロドスの壁とが交わる劇場東西南端付近には、南側外部 から出入りするための大階段が残つている。これらを南西大階段、 南東大階段とする。南西大階段は、幅約 $5.5 \mathrm{~m}$ にわたつて石材が並 べられており、階段の踏み面は約 $0.7 \mathrm{~m}$ であった。

\section{4. 客席の建築部材}

\section{4-1. 座席部材}

メッセネの劇場で使用された座席は、材料および工法の点で 3 種 類あることを確認した。

第一に、高さ $0.41 \mathrm{~m}$ 座面幅 $0.399 \mathrm{~m}$ のポロス材からなる座席であ る。この種の座席は、3 種の座席部材の中では最も古いものだと考 えられる。客席最下段の 1 段のみに使用されている。全体的に残り が悪いが、これらのうち比較的残りがよい部材 1 個を実測したとこ ろ、部材高さ $0.410 \mathrm{~m}$ 、底面幅 $0.302 \mathrm{~m}$ 、座面幅 $0.399 \mathrm{~m}$ であった。

第二に、石灰岩製の板石を垂直と水平に組み合せた座席であり、 ディルケ氏による分類ではアルゴス型にあたる ${ }^{12}$ 。遺構の現状より、 客席の 2 段目から数段は、この種の座席が使用されたことがわかる。 水平に設置された板材は座面用と足置き用の 2 種類があり、客席の 南西から 2 番目のクネイに残る座席 2 段を実測したところ、座面用 の部材は厚さ $0.14 \mathrm{~m}$ 、奥行き $0.35 \sim 0.36 \mathrm{~m}$ 、足置き用の部材は厚さ 不明、奥行き $0.37 \sim 0.38 \mathrm{~m}$ 、垂直に設置された板材は足置き用部材 上面から高さ約 $0.25 \mathrm{~m}$ であった。座面用の部材は、設置する際に垂

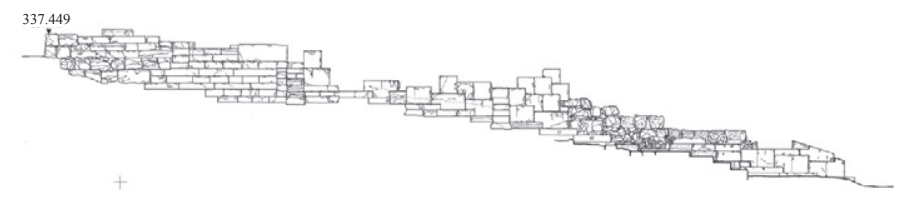

西パラドスの壁

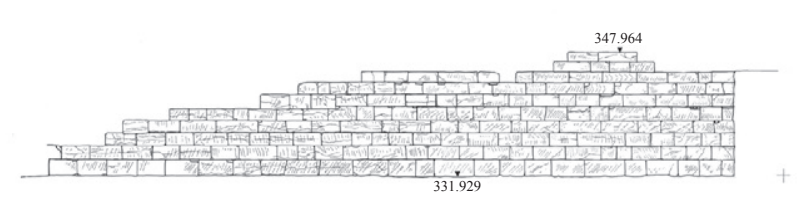

舞台収納庫の壁

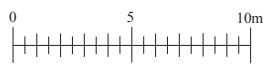

図 3 西パラドスおよび東舞台収納庫の壁の南立面図

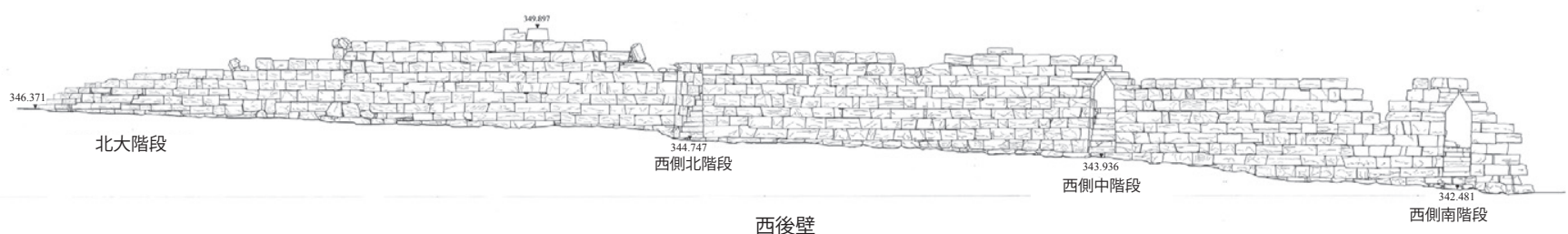

西後壁 西側南階段

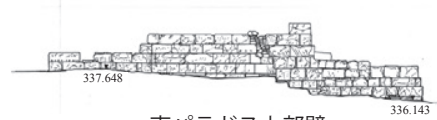

東パラドス上部壁

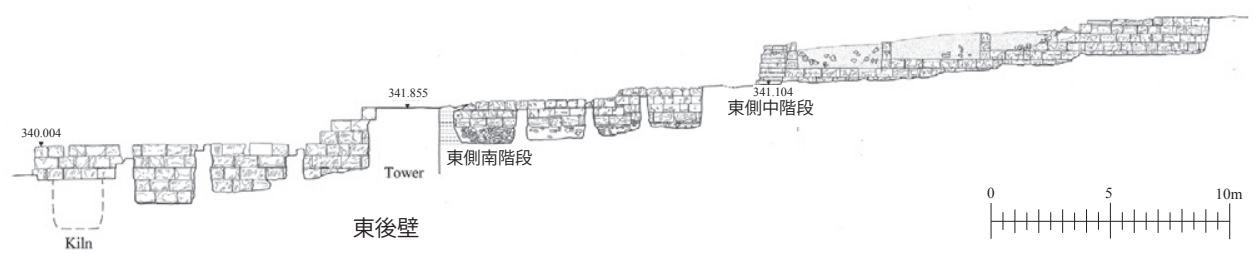

図4 東西後壁および東パラドス上部壁の立面図 


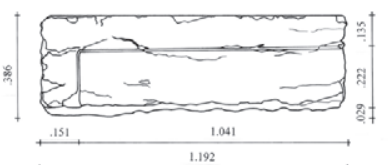

(ア)

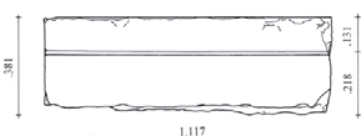

(イ)

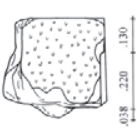

$\stackrel{.022}{+}$

(ウ )

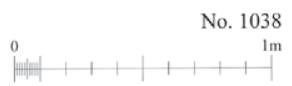

図 5 座席部材

（ア）左端座席部材 (No. 1020)（イ）中間座席部材 (No. 1013) (ウ) 右端座席部材 (No. 1038)

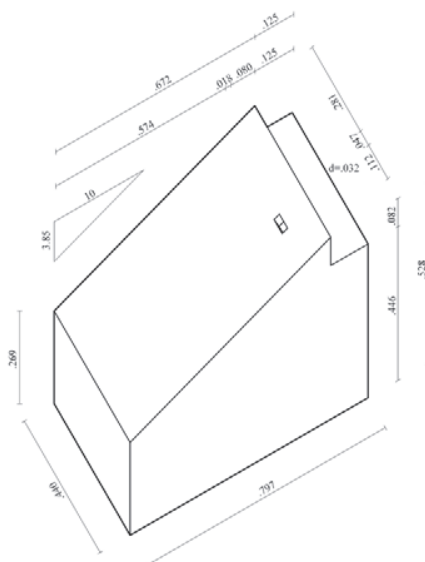

図 6 東パラドスの壁部材
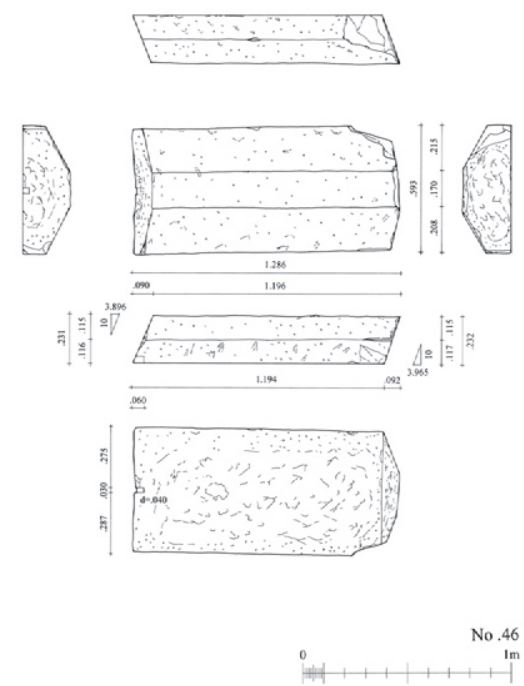

図 7 パラドスの壁の笠木部材
直に置かれた石材の前面より 20 ～40mm ほど出るように配置され ている。劇場遺構から出土した石灰岩製板材の多くは、現在別所に て保管されているが、2012 年度の現地調査時にこれらの石灰岩製板 材の観察をおこなったところ、後述する高さ座面幅ともに $0.35 \mathrm{~m}$ の 石灰岩製部材の前面につけられている帯装飾や、背面および底面の こぶ状になっている粗仕上げ部分の痕跡があるものが多数発見され た。これらのことから、この種の板材には、後述する石灰岩部材を 再加工したものが含まれており、3 種の座席の中で最も新しいもの である可能性が高い。

第三に、高さ座面幅ともに $0.35 \mathrm{~m}$ 程度の石灰岩製部材である (図 5)。この種の部材は 536 個確認され、このうち 6 個の実測図を作成 し、残り 530 個の各部寸法を計測した。座面を構成する石灰岩部材 は、前面と上面を上仕上げとしているが、背面と底面をこぶ状の粗 仕上げとしている。座面部材前面の高さは平均 $0.358 \mathrm{~m}$ (最小 $0.294 \mathrm{~m}$ 最大 $0.419 \mathrm{~m}$ ) で、上面幅は平均 $0.350 \mathrm{~m}$ (最小 $0.296 \mathrm{~m}$ 最大 $0.410 \mathrm{~m}$ ) で ある。部材前面につけられた帯の形から、それらが置かれていた位 置を推定することができる。発見された 536 部材のうち、座席を才 ルケストラから見たときに右端におかれたと考えられる部材は 112 個、中間に置かれたと考えられる部材は 133 個、左端におかれたと 考えられる部材は 98 個、残り 193 個は不明であった。帯装飾の幅 は平均 $0.131 \mathrm{~m}$ で、部材前面から平均 $0.022 \mathrm{~m}$ 出ている。これと同じ 形状の座席部材が、同じメッセネのスタディオンとエクレシアステ リオンでも使用されており、おそらくこれらと同様に前述の石灰岩 部材で座面を構成し、石灰岩製の板材を用いて足置きを構成したと 考えられる ${ }^{13)}$ 。この種の座席は、ディルケ氏の分類によるとメガロ ポリス型にあたる。

\section{4-2. パロドスの壁部材}

パロドスの壁は、ポロス材あるいは石灰岩の部材で構成されてい る。壁の最上段に置かれた部材は、上面が地面に対して斜めに切断 されており、著者らはこれらのうち状態のよいもの 2 個の実測をお こなった。一方は東パロドスから出土したポロス材の部材であり、
上面の傾斜は 22.1 度である（図 6)。もう一方は、西側のパロドス の壁のオルケストラ近くに置かれた状態の部材であり、石灰岩製で、 上面の傾斜は 21.1 度である。

\section{4-3. パロドスの壁の笠木部材 ( 図 7)}

パロドスの壁の上には、通常笠木部材が置かれる。メッセネの劇 場では、石灰岩製の笠木部材が発見されている。著者らは、7 個の 笠木部材を実測した。部材の長さは $0.78 \sim 1.3 \mathrm{~m}$ 、高さは $0.19 \sim 0.23 \mathrm{~m}$ である。部材上面両側を面取りしており、7 個のうち 5 個のみ実測 が可能であったため計測したところ、部材両端の接合面は底面に対 して平均 21.35 度 (最小 19.12 度最大 22.90 度) 斜めに切られている。 この角度は客席の勾配に合わせており、本部材をパロドスの壁の上 に置いた際には、接合面が地面と垂直になったと考えられる。

\section{5. 客席部の推定復元}

本章では、現地調査で得られた遺構と建築部材の情報をもとに、 以下の手順で劇場客席部の復元を試みる。まず、周回通路の本数と おおまかな位置を出し、客席の層数を求める。次に、座席や階段通 路の勾配、各部寸法の復元值を算出し、その結果をもとに客席部の 復元をおこなう。なお、高さについては、現地にてトータルステー ションを用いて計測した標高をもとに、オルケストラの床面を高さ $0 \mathrm{~m}$ とした時の比高を記す。ただし、現状図中には標高を記す。

\section{5-1. 客席の層数}

本節では、遺構の現状から周回通路の数を明らかにし、客席が何 層構成であったかを考える。

現在、周回通路は残っていないが、その痕跡と思われる遺構が 3 箇所で確認される。1 箇所目は、客席西中腹に出土した石材列であ る。この石材列は、石灰岩材列の上にポロス材列が載るかたちとなつ ており、石灰岩材列上面は高さ $9.037 \mathrm{~m}$ 、オルケストラ中心から石材 列前面までの水平距離は $33.540 \mathrm{~m}$ である。ポロス材列は、周回通路 の基礎であった可能性が示唆される。2 箇所目は、オルケストラ中 心から $31.758 \mathrm{~m}$ の地点で幅約 $35.00 \mathrm{~m}$ にわたって西パロドスの壁の 
一部が切れ、石灰岩製の石材で舗装された床のようなものが見えて いる部分で、床面高さ $5.855 \mathrm{~m}$ である。3 箇所目は、東後壁の南端部 に設けられている斜路である。この斜路は、オルケストラ中心から $33.45 \sim 38.49 \mathrm{~m}$ の位置で北へ曲がっていることから、曲がった先に 周回通路があった可能性が高い。以上より、高さ $9.037 \mathrm{~m}$ 前後、才 ルケストラ中心から $33.5 \mathrm{~m}$ 付近に周回通路があったと考えられる。

この周回通路とは別に、さらに標高が高い位置にもう一本周回通 路があったと考えられる。後壁に設けられた階段を見てみると、各 階段前の街路標高が異なる。最も標高が低いのは東側中階段前で、 高さ $9.453 \mathrm{~m}$ である。これと座席西中腹の石灰岩材列の高さ $9.037 \mathrm{~m}$ とを比較すると、東側中階段前の街路標高が $0.416 \mathrm{~m}$ 高い。つまり、 東側中階段を上ると石灰岩材列より高い位置に出ることになる。他 の階段も同様に、階段前の街路の標高が前述の石灰岩材列より高い。 したがって、高さ $9.037 \mathrm{~m}$ の周回通路よりさらに高い位置にもう 1 本周回通路があり、そこへ各階段が接続していたと考えられる。

以上より、本劇場には、 2 本の周回通路があり、客席全体を 3 層 に分けていたと考えられる。以下、2 本の周回通路を下部周回通路、 上部周回通路とし、客席各層を下層から順に第 1 層、第 2 層、第 3 層とする。次節以降、客席各層の詳細な復元分析をおこなう。

\section{5-2. 客席第 1 層の復元}

1）下部周回通路の復元

周回通路の幅と後背部の壁の高さは明らかでないが、メッセネの 劇場と同規模でギリシアにある、エピダウロス、アルゴス、メガロ ポリス、スパルタの劇場の例から、下部周回通路は、通路幅 1 $2 \mathrm{~m}$ 、通路の後背壁の高さ $1 \sim 1.5 \mathrm{~m}$ 程度、後背壁の幅 $1.2 \mathrm{~m}$ 前後であつ たと推測される ${ }^{14)}$ 。本稿では、下部周回通路の寸法が、劇場の規模 がほぼ同じで、かつ建物全体の残りがよいエピダウロスの劇場の周 回通路の寸法、幅 $1.830 \mathrm{~m}$ 、後背部の壁の高さ $1.350 \mathrm{~m}$ 、後背壁の奥 行き $1.210 \mathrm{~m}$ を用い、推定復元をおこなう。また、周回通路前方に は客席最上段の座席が置かれ、通路幅は座席後端部から通路後背壁 前面までの幅とする。

下部周回通路があった位置は、前節のとおり、オルケストラ中心 から約 $33.5 \mathrm{~m}$ の地点であったと考えられる。この付近で出土した遺 構は、客席西中腹の石材列、西パロドスの壁中腹の石灰岩、東後壁 南端部の斜路が北へ曲がる地点にあるポロス材列である。これらの うち、客席西中腹の石材列が最も標高が高い位置で出土しており、 その高さ $9.037 \mathrm{~m}$ 付近に下部周回通路があったと考えられる。客席 西中腹の石材列を見てみると、石灰岩材列の上部にポロス材列が 載っている。このことから、石灰岩材列が下部周回通路床面の仕上 げ材でポロス材列が通路後背部の壁の基礎部材であったか、石灰 岩材列が座席の仕上げ材でポロス材列が下部周回通路の基礎部材で あった可能性が示唆される。

石灰岩材列が客席の仕上げ材でポロス材列が下部周回通路の基礎 部材であった場合、ポロス材列の前面が下部周回通路前面にあたり、 オルケストラ中心から通路前面までの水平距離は $33.710 \mathrm{~m}$ となる。 これは、西パロドスの途中にある床のような石灰岩列の位置（オル ケストラ中心から 31.76 35.25m) や東後壁南端部の斜路が北へ折れ 曲がる位置 (オルケストラ中心からの水平距離 33.45 38.49m) と矛 盾しない ${ }^{15)}$ 。したがって、客席西中腹の石材列のうち下段の石灰岩 材列は座席の仕上げ材、上段のポロス材列は下部周回通路の基礎部
材だったと判断する。

表 1 笠木上面の傾斜

ここで、下部周回通路の前方には座席があ り、基礎となっていたポロス材列の上面と前 面には石灰岩の板材を貼って仕上げ面として いたと考えられるため、それを踏まえて通路 の正確な位置を推定復元する。客席 $2 、 3$ 段 目に使用されている、板石を水平垂直に組み 合せた座席の部材寸法をもとに、下部周回通 路前方座席は奥行き $0.360 \mathrm{~m}$ 、座面の板材は

\begin{tabular}{|c|c|}
\hline 部材番号 & 傾斜(度) \\
\hline T44 & 22.2 \\
\hline & 21.0 \\
\hline T66 & 19.1 \\
\hline & 23.0 \\
\hline 45 & 21.8 \\
\hline & 22.7 \\
\hline T46 & 21.3 \\
\hline & 21.6 \\
\hline T62 & 19.6 \\
\hline 平均 & 21.4 \\
\hline
\end{tabular}
高さ $0.140 \mathrm{~m}$ 、座席前面に貼られた仕上げ材 は厚さ $0.070 \mathrm{~m}$ とする (図 9b)。また、通路床面は座席上面より $0.070 \mathrm{~m}$ 低かったとして、下部周回通路の床面は高さ $9.507 \mathrm{~m}$ 、通路前方の座 席は高さ $9.577 \mathrm{~m}$ の位置にあったと復元する。オルケストラ中心か ら下部周回通路前面までの水平距離は、 $33.990 \mathrm{~m}$ となる。

\section{2）客席第 1 層の座席勾配の復元}

客席第 1 層の座席勾配の復元にあたっては、まず前項で復元した 下部周回通路の位置から勾配を算出する。続いて、パロドスを構成 した壁部材、笠木部材、階段通路の蹴上と踏み面の寸法值をもとに 勾配を計算する。最後に、これらを比較して復元勾配を決定する。

前述のとおり、客席西中腹の石灰岩材列が客席第 1 層の上から 2

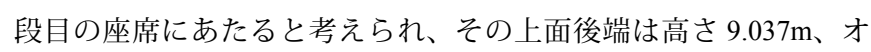
ルケストラ中心からの水平距離 $33.640 \mathrm{~m}$ の位置にあったと推測され る。これは、下部周回通路前方の座席の前面下端の位置となる。一 方、客席最下段を見ると、エウリポス外縁に沿ったポロス材の座席 が置かれ、その横に階段通路の 1 段目が設置されている。階段 2 段 目の前面下端は座席 2 段目の足置きの位置にあたり、高さ $0.540 \mathrm{~m}$ 、 オルケストラ中心からの水平距離 $12.374 \mathrm{~m}$ である。階段 2 段目 の前面下端から下部周回通路前面下端までの水平距離は 33.64012.374=21.266m で、両者間の高低差は 9.037-0.540=8.497m、両者を 結んだ斜辺の傾斜角は $\tan ^{-1}(8.497 / 21.266)=21.78$ 度となる。

東西パロドスの壁部材のうち、上面が斜めに切られた壁部材 2 個 の上面の傾斜を計測したところ、21.1 度と 22.1 度で、平均 21.6 度 であった。また、パロドスの頂部に置かれた笠木部材 7 個の、隣接 する部材との接合面に対する上面の傾きを実測したところ、最小 19.1 度、最大 23.0 度、平均 21.4 度であった (表 1 )。

階段通路は、現在残つている 10 本の階段通路のうち、計測が可 能だったのは 8 本で、段数にして 65 段であった。計測の結果、蹴 上は平均 $0.142 \mathrm{~m}$ (最小 $0.097 \mathrm{~m}$ 最大 $0.220 \mathrm{~m}$ ) 、踏み面は平均 $0.364 \mathrm{~m}$ (最 小 $0.290 \mathrm{~m}$ 最大 $0.460 \mathrm{~m})$ であった。これらの計測結果から階段状通 路の勾配を算出すると、最小 13.59 度、最大 32.45 度、平均蹴上・ 平均踏み面から計算した勾配は2 1.31 度となる。

以上より、パロドス壁部材上面の傾斜が平均 21.6 度、パロドスの 笠木部材の傾斜が平均 21.4 度、階段通路の勾配が平均 21.31 度とい う結果が得られた。これらは、下部周回通路前方の座席前面下端と 階段通路 2 段目前面下端を結んだ斜辺の傾斜角 21.78 度と大差ない。 したがって、客席第 1 層の階段通路および座席は、勾配 21.78 度で 積まれたとする。

3）客席第 1 層の座席および階段通路の復元

客席第 1 層の座席は、ポロス材の座席と 2 枚の板石を水平垂直に 組み合せた座席との 2 種類があったと考えられる (図 9a、b)。最下 
部でオルケストラと接する部分には、エウリポスのすぐ外側にポロ ス材の座席が置かれていた。座席 $2 \sim 4$ 段目には、現在も座席の一 部が残っており、加えて、客席西中腹の石灰岩材列が上から 2 段目 の座席上面の板石にあたると推測されることから、客席第 1 層では 座席 2 段目から最上段まで、石灰岩製の板石を水平垂直に配置する 座席が使用されたと考えられる (図 8 上)。客席第 1 層の上から 2 段目の座席の奥行きは、客席西中腹の石灰岩材列前面から復元した 下部周回通路前面までの奥行きに等しく、0.730m となる。座面の板 石は、その下部に垂直に置かれた板石より前へ出ていると考えられ る。どれくらい出ていたかは不明であるが、本稿では、高さ座面幅 ともに $0.35 \mathrm{~m}$ の石灰岩製座席部材の前面に施された帯装飾の平均高 さと同じ $0.022 \mathrm{~m}$ 出ていたとする。すると、垂直に置かれた石材前 面から座席後端までの奥行きは $0.730-0.022=0.708 \mathrm{~m}$ となる。一般に、 座席 1 段につき階段通路の階段 2 段が設置されることから、階段 2 段分の踏み面を足したものが $0.708 \mathrm{~m}$ と考えると、階段 1 段分の踏 み面は $0.708 / 2=0.354 \mathrm{~m}$ となる。踏み面 $0.354 \mathrm{~m}$ の階段を勾配 21.78 度で積む場合、階段 1 段分の蹴上は、 $0.354 \times \tan 21.78^{\circ} \fallingdotseq 0.141 \mathrm{~m}$ と なる。この結果を、遺構の実測值から算出した平均值と比較すると、 蹴上の現状平均 $0.141 \mathrm{~m}$ との誤差は $0.00 \mathrm{~m}$ 、踏み面の現状平均 $0.364 \mathrm{~m}$ との誤差は $0.010 \mathrm{~m}$ である。

階段通路の 2 段目以降の階段が、すべて蹴上 $0.141 \mathrm{~m}$ 踏み面 $0.354 \mathrm{~m}$ であった場合、階段通路の階段 2 段目の前面下端から下部周回通 路前方の座席前面下端までの間に、8.497/0.141=60 段余り $0.037 \mathrm{~m}$ 、 $21.266 / 0.354=60$ 段余り $0.026 \mathrm{~m}$ より、60 段入る。しかし、階段がこ こへ奇数段入らなければ客席 1 段あたりに階段が 2 段ずつおさまら ないため、階段通路の階段 2 段目前面下端から下部周回通路前方 の座席前面下端までの間に 59 段の階段が入っていたとする。 59 段 のうち最上段 2 段分は、客席西中腹の石灰岩材列の奥行きから計 算した蹴上 $0.141 \mathrm{~m}$ 踏み面 $0.354 \mathrm{~m}$ とし、残り 57 段分の蹴上と踏み 面を再計算し、蹴上 $(8.497-0.1414 \times 2) / 57=0.144 \mathrm{~m}$ 、踏み面 $(21.266-$ $0.354 \times 2) / 57=0.361 \mathrm{~m}$ とする。これらと遺構の実測值より算出した平 均值とを比較すると、蹴上の現状平均 $0.141 \mathrm{~m}$ との䛊差は $0.003 \mathrm{~m}$ 、 踏み面の現状平均 $0.364 \mathrm{~m}$ との䛊差は $0.003 \mathrm{~m}$ である。本稿では、便 宜的に一定の蹴上と踏み面をもって階段通路を復元する。また、階 段通路の最上段 2 段分は、客席西中腹のポロス材列の高さ $0.400 \mathrm{~m}$ に復元した床材の厚さ $0.070 \mathrm{~m}$ を足した $0.470 \mathrm{~m}$ を階段 2 段分の蹴上 とし、蹴上 $0.470 / 2=0.235 \mathrm{~m}$ 、踏み面は $0.350 \mathrm{~m}$ とした。階段通路は 合計 62 段、座席は 31 段あったと復元される。

階段通路の位置は、オルケストラ周辺に残る階段通路の痕跡より、 第 1 層には合計 10 本の階段通路があり、客席は 11 クネイに分割さ れる。客席の両南端に、階段通路はない。通常、階段通路は、オル ケストラの中心に向かって放射状に配置されるが、現状では各階段 の延長状にオルケストラの中心がない。本稿では、現状の各階段通 路の軌道を延長して復元をおこなう。

\section{5-3. 客席第 2 層、第 3 層の復元}

\section{1）上部周回通路の復元}

上部周回通路は、下部周回通路と同じ幅 $1.830 \mathrm{~m}$ 、後背壁の高さ $1.350 \mathrm{~m}$ 、後背壁の幅 $1.210 \mathrm{~m}$ として復元をおこなう。

上部周回通路は、東西後壁に取り付けられた 6 本の階段 (西側北 階段、西側中階段、西側南階段、東側北階段、東側中階段、東側
南階段) を通り、東西後壁外側の街路から出入りするようになって いたと考えられる。前述の 6 本の階段のうち、現状で最も標高が高 いところまで階段が残っているのは西側北階段で、最上段は高さ $16.299 \mathrm{~m} 、 2$ 番目が西側中階段で、最上段は高さ $14.600 \mathrm{~m}$ である。こ のどちらかが、上部周回通路の床面と同じ高さであったと仮定する。 西側北階段の最上段の高さが上部周回通路の床面標高であったと すると、上部周回通路は高さ $16.299 \mathrm{~m}$ 以上の地点にあったと言える。 高さ $16.299 \mathrm{~m}$ まで他の階段を積んでいったとき、西側南階段がオル ケストラ中心から最も近い位置で高さ $16.299 \mathrm{~m}$ に達し、この時、才 ルケストラ中心から階段最上段後端までの水平距離は $45.796 \mathrm{~m}$ と なる。西側南階段の最上段後端を上部周回通路後端とすると、上部 周回通路前面から下部周回通路の後背壁上面後端までの水平距離が (45.796-1.830)-(35.820+1.210)=6.930m、上部周回通路床面と下部周回 通路後背壁上面との高低差が 347.950-342.538 $=5.412 \mathrm{~m}$ となり、座席 勾配は $\tan ^{-1}(5.412 / 6.930)=37.99$ 度となるが、これは客席勾配として は急すぎる ${ }^{16)}$ 。そのため、上部周回通路が西側北階段の最高段と同 じ高さ $16.299 \mathrm{~m}$ にあったとは考えにくい。

次に、2 番目に高い位置まで階段が残っている西側中階段の最上 段の高さ $14.600 \mathrm{~m}$ を、上部周回通路の床面標高と仮定する。西側北 階段は、すでに高さ $16.299 \mathrm{~m}$ まで階段があるため、下り階段を設 けなければ上部周回通路へ接続することができないが、基本的にす べての階段が上り階段のみで通路へ接続したと考えられるので、西 側北階段は上部周回通路より高い位置で客席に接続していたと推測 される。西側北階段以外の各階段を高さ $14.600 \mathrm{~m}$ まで積むと、才 ルケストラ中心から最も近い位置でこの高さへ到達するのが西側 南階段で、オルケストラ中心から階段最上段前面までの水平距離が
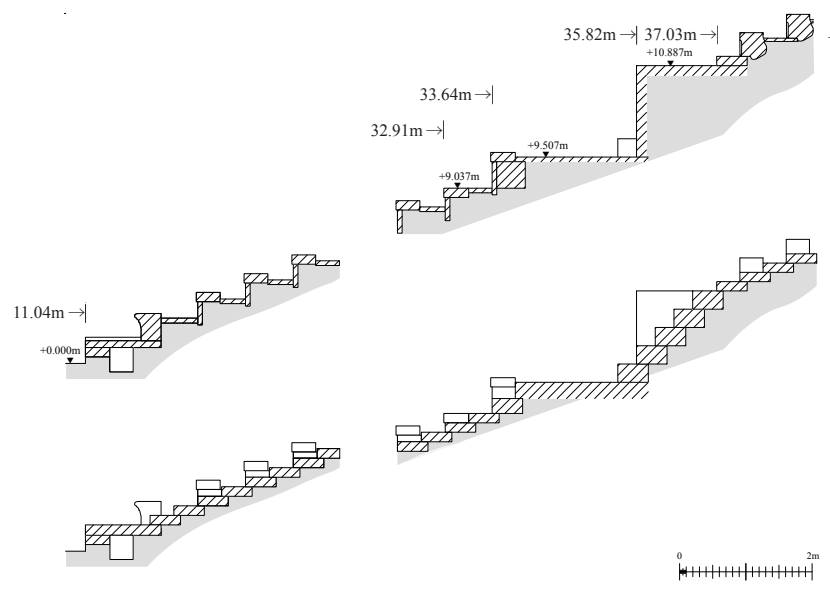

図 8 座席詳細復元断面図

左上; 最下段付近の座席、右上; 客席第 1 層最後部、下部周回通路、客席第 2 層最下部の座席 左下；最下段付近の階段、右上；客席第 1 層最後部、下部周回通路、客席第 2 層最下部の階段

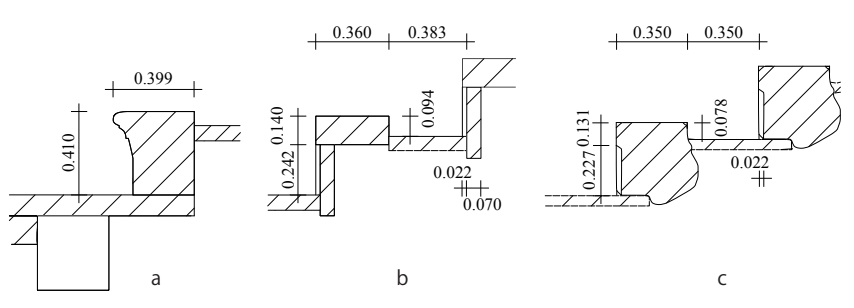

図 93 種類の座席構成 a; ポロス材の座席、 b; 2 枚の板石を水平垂直に組み合せた座席、 c; 幅高さ $0.35 \mathrm{~m}$ の石灰岩製部材と板石を組み合わせた座席 
$48.232 \mathrm{~m}$ となる。上部周回通路前面から下部周回通路後背壁の上面 後端までの水平距離は (48.232-1.830)-37.030=9.372m、両者の高低差 は 14.600-10.887=3.713m となる。これらの值より、座席勾配は $\tan$ ${ }^{1}(3.713 / 9.372)=21.61$ 度と算出され、客席第 1 層の座席勾配とほぼ等 しい值となる。したがって、上部周回通路の床面標高は西側中階段 の最上段の高さ $14.600 \mathrm{~m}$ と同じと判断する。

西側中階段は、オルケストラ中心から階段最上段後端までの水平 距離が $51.140 \mathrm{~m}$ であるので、51.140-48.232=2.908m より、階段の最 上段から通路までに長さ $2.908 \mathrm{~m}$ の水平通路を設けることで上部周 回通路へ出ることとする。この階段以外では、東側北階段がオルケ ストラ中心から $50.920 \mathrm{~m}$ の位置で高さ $14.600 \mathrm{~m}$ に達するため、 $2.674 \mathrm{~m}$ の水平通路を設ける必要がある。東側中階段はオルケストラ中心か ら $48.412 \mathrm{~m}$ 、東側南階段はオルケストラ中心から $48.762 \mathrm{~m}$ の位置で 高さ $14.600 \mathrm{~m}$ に達するため、それぞれに $0.018 \mathrm{~m}$ と $0.530 \mathrm{~m}$ の水平通 路を設ける必要があるが、これは通路というよりは階段の踏み面に 相当すると言える。

\section{2）客席第 2 層の座席勾配の復元}

客席第 2 層の客席の勾配は、下部周回通路と上部周回通路と の距離と高さより復元值を算出する。前項で述べたとおり、上 部周回通路前面から下部周回通路後背壁の上面後端までの水平

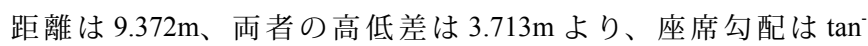
${ }^{1}(3.713 / 9.372)=21.61$ 度と算出される。この值は、客席第 1 層の勾配 21.78 度と比べるとやや緩やかだがほぼ同值であるため、第 1 層の 勾配に合わせて第 2 層の勾配も 21.78 度として復元をおこなう。客 席第 3 層の勾配は、客席最後部の標高が不明なため、客席第 1 層、 第 2 層の勾配と同じく 21.78 度として復元をおこなう。これに伴い、 上部周回通路の寸法を再計算し、復元をおこなう。

\section{3）客席第 2 層の階段通路および座席の復元}

客席第 2 層の階段通路は、現在痕跡が全く残っていないため、そ の配置については類例を参照して復元せざるをえない。階段通路の 配置に関しては、3 層構成の劇場で階段の数が上層と下層で異なる 場合、客席第 1 層の階段通路の数にくらべ客席第 $2 、 3$ 層の階段通 路の数が 2 倍になる例 (例: アテネのディオニソス劇場) と、客席第 1 、 2 層の階段通路の数が同じで第 3 層の階段通路の数が 2 倍になる例 (例 : エフェソスの劇場 ) がある ${ }^{17}$ 。本稿では、客席第 2 層の階段通 路は第 1 層の階段通路と同数であったとする。

客席第 2 層の座席は、高さ $0.358 \mathrm{~m}$ 幅 $0.350 \mathrm{~m}$ の石灰岩製の部材を 座面に使用し、足置きに板材を使用したと考えられる (図 9c)。こ れは、この種の座席部材が、客席があった斜面中腹で出土したため である (図 1)。座席 1 段分の幅は座面幅の 2 倍と考え、 $0.350 \times 2=0.700 \mathrm{~m}$ とする。通常、座席 1 段分の奥行きが階段通路の踏み面 2 段分と なるので、階段の踏み面は $0.700 / 2=0.350 \mathrm{~m}$ となる。踏み面 $0.350 \mathrm{~m}$ の階段を勾配 21.78 度で積むとき、蹴上は $0.350 \times \tan 21.78^{\circ}=0.1398 \mathrm{~m}$ となる。客席第 2 層には、蹴上約 $0.140 \mathrm{~m}$ 踏み面 $0.350 \mathrm{~m}$ の階段が、 $3.713 / 0.1398=26$ 余り $0.078 \mathrm{~m} 、 9.368 / 0.350=26$ 余り $0.272 \mathrm{~m}$ より 26 段あり、最上段のみ蹴上 $0.218 \mathrm{~m}$ とし、上部周回通路の前面を $0.272 \mathrm{~m}$ 前へ出し通路幅を $1.830+0.272=2.102 \mathrm{~m}$ とすることで調整する。客席 第 2 層には、座席が $26 / 2=13$ 段あったと復元される。

4）客席第 3 層の階段通路、客席および最後部通路の復元 第 3 層の階段通路は、後壁の階段が客席第 1 層の 2 本の階段通路
のほぼ中間に位置するため、第 2 層の階段通路の延長線上および 2 本の階段の中央に配置されたとする。ただし、西側中階段、西側南 階段、東側北階段のある位置については、階段通路はなかったと考 えられる。東側中階段以南は後壁が約 $3.9 \mathrm{~m}$ オルケストラに近づい て造られているため、この部分に客席第 3 層の座席はなかったと考 えられる。以上より、客席第 3 層は、12 本の階段通路と 4 本の階段 により 16 クネイに分割されていたとする。後壁南部のみがオルケ ストラに近い理由は不明だが、後壁外側の街路や街路を挟んで隣接 するアルシノエの泉の建物と関連する可能性がある。階段通路は、 客席第 2 層と同じ蹴上 $0.1398 \mathrm{~m}$ 踏み面 $0.350 \mathrm{~m}$ で積まれたとする。

西後壁に設けられた北大階段は、客席最後部に接続していたと 考えられるため、客席最後部にも通路があると考えられる。現在、 北側大階段は西後壁から外部へ突出する形で下部が全長 $8.64 \mathrm{~m}$ 幅 $2.58 \mathrm{~m}$ にわたって残っている。階段は最下段から 4 段目まで残って おり、このうち残りがよい 3 段を計測したところ、平均踭上 0.268 $\mathrm{m}$ （最小 $0.255 \mathrm{~m}$ 、最大 $0.285 \mathrm{~m}$ ）踏み面は全段 $0.360 \mathrm{~m}$ であった。水 平距離 $8.64 \mathrm{~m}$ にわたって蹴上 $0.268 \mathrm{~m}$ 踏夕面 $0.360 \mathrm{~m}$ の階段が積まれ た場合、8.64/0.360=24 より、劇場内に入るまでに 25 段の階段があっ たと考えられる。さらに、厚さ $1.4 \mathrm{~m}$ の後壁内を通り劇場最後部へ 出るまでに階段があったとすると、 $1.40 / 0.360=3$ 段余り $0.320 \mathrm{~m}$ より、 先述の 25 段に 4 段の階段が加えられ、合計 29 段の階段があったと 推算される。階段 3 段目までを現状の蹴上で積み、4 段目以降を蹴 上 $0.268 \mathrm{~m}$ で積むと、北側大階段全段を合計した高さは $0.255+0.265$ $+0.285+0.268 \times 26=7.773 \mathrm{~m}$ となる。階段前の地表面が高さ $14.720 \mathrm{~m}$ で あることから、北大階段の最上段の高さは $14.720+7.773=22.493 \mathrm{~m}$ と 復元される。

客席第 3 層の座席は、客席第 2 層と同様に高さ $0.358 \mathrm{~m} 、$ 幅 $0.350 \mathrm{~m}$ の石灰岩部材と幅 $0.350 \mathrm{~m}$ の板石とを組み合わせて構成したと考え られる (図 9c)。また、上部周回通路の後背壁が $1.380 \mathrm{~m}$ 立ち上がり、 後背壁の幅が $1.210 \mathrm{~m}$ とすると、客席第 3 層最前列の座席の足置き 前面下端は、高さ $14.600+1.380=15.980 \mathrm{~m}$ 、オルケストラ中心から の水平距離 $48.232+1.210=49.442 \mathrm{~m}$ の位置にあったということにな る。階段通路の最上段が前述の北大階段の最上段の標高と同じ標高 であったとすると、最後部通路床面と上部周回通路後背壁上面との 高低差は 22.493-15.980=6.513m で、6.513/0.1398=46 段余り $0.082 \mathrm{~m}$ より、46段の階段があったとする。踏み面 $0.350 \mathrm{~m}$ の階段を 46 段 積むと、オルケストラ中心から階段通路最高段前面までの水平距 離は $49.442+(0.350 \times 45)=65.192 \mathrm{~m}$ となる。客席第 3 層には、座席が $46 / 2=23$ 段あり、客席最後部通路は最大幅約 $7 \mathrm{~m}$ の踊り場状の場所 であったと推定される。

\section{5-4. 東西パロドスの復元}

\section{1）東パロドスの復元}

第 3 章で述べたとおり、東パロドスの壁のすぐ南には舞台収納庫 の石灰岩で作られた壁があり、両者の間には大小の石材が充填され ている。この壁は舞台収納庫の北壁にあたり、南壁は基礎部のみ残つ ている。これらのことから、後 1 世紀から後 3 世紀までの最終段階 で外部に露出していたのは、舞台収納庫の壁であったと考えられる。 壁上部には、劇場東側からの主要な通路があり、上部座席を支え る壁が設けられている。この部分は斜路となっており、下部周回 通路へ出入りすることができる。斜路の現状の高さ $5.997 \mathrm{~m}$ と下部 


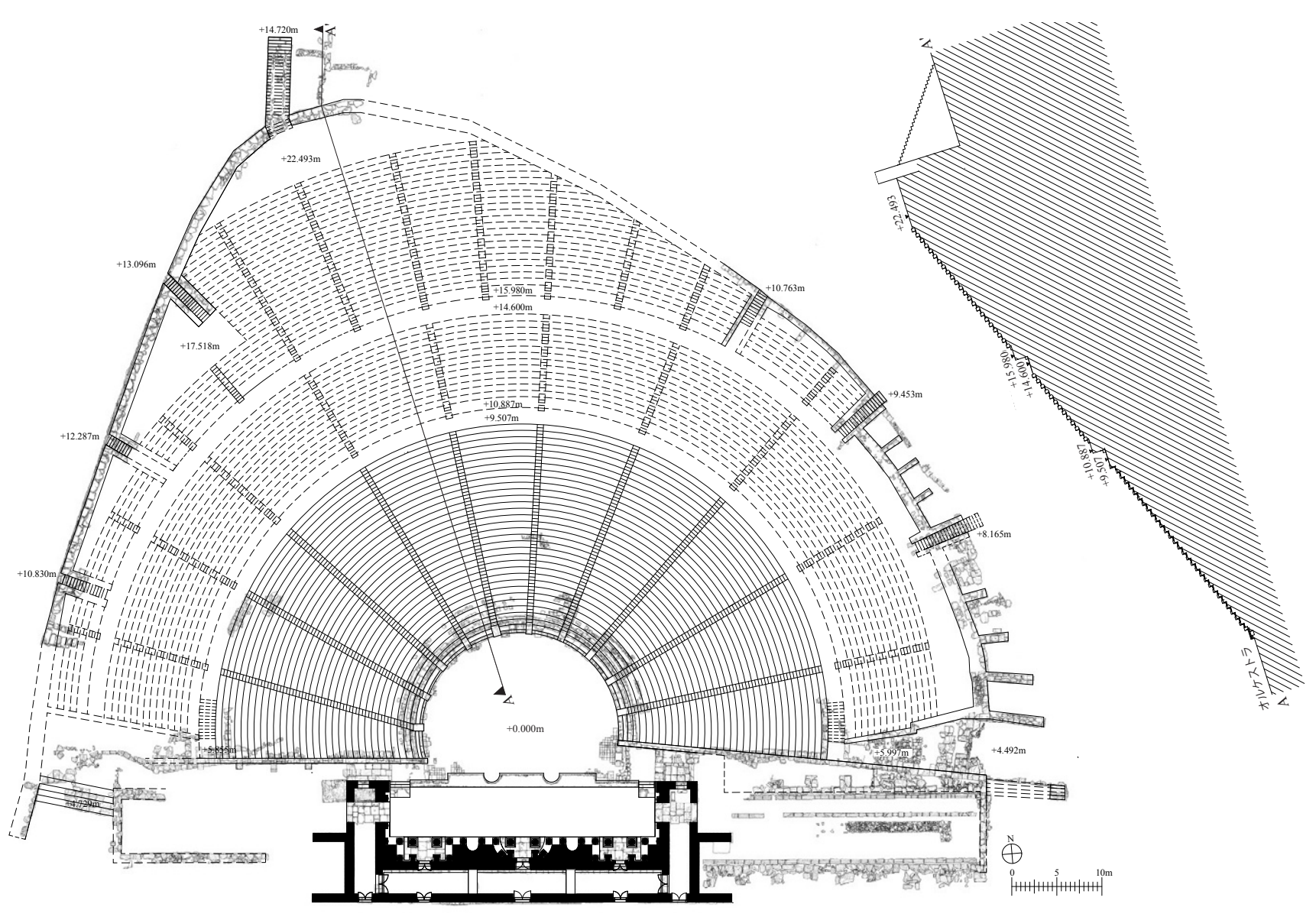

図 10 劇場客席の平面、断面復元試案

周回通路床面の復元高さ $9.507 \mathrm{~m}$ との高低差が 5.997-9.507=3.510m あるので、斜路と周回通路との間に階段を設けたと考えられる。 この階段は、北大階段と同じく蹴上 $0.268 \mathrm{~m}$ 踏み面 $0.360 \mathrm{~m}$ とし、 $3.510 / 0.268=13$ 余 $0.026 \mathrm{~m}$ より、合計 13 段あったと推定する。

\section{2）西パロドスの復元}

西パロドスの壁は、ヘレニズム期の壁の痕跡が残っているが、ロー マ時代には舞台建物と壁は平行であったと考えられる。壁東部では 石灰岩材が積まれた壁の後ろにポロス材の列が見つかっていること から、ヘレニズム期の壁の部材を一部再利用して壁を構成している と推測される。

壁の西端部には、東パロドス壁東端部と同じく階段が一部残って いることから、劇場南西部からの主要な出入口となっていたと考え られる。おそらく、東パロドスと同様に階段から続く通路があり、 下部周回通路へ接続していたと考えられる。西パロドスの壁が一部 切れ、床面が露出している部分は、おそらく劇場南西部から下部周 回通路へ出入りするための通路の一部であったと考えられる。

\section{6. 結論}

以上、メッセネの劇場の客席部の現状を報告し、ローマ時代にお ける客席部の復元試案を提示した (図 10)。

前章で提示した復元案は客席第 2、3 層の座席勾配や上部周回通 路の位置、各周回通路の幅や後背壁の高さなどは、それらを直接特 定できる遺構が残っていないために推測の域を超えないが、客席が 3 層構成で、2 本の周回通路が存在した可能性は極めて高い。また、
客席第 1 層の階段通路が 10 本で客席が 11 クネイに分割されていた ことは、遺構の現状より確実と言える。座席は 3 種類あり、その中 にはおそらくへレニズム期に使用されていた部材が含まれていた。 座席以外にも、ローマ時代のパロドスの壁は、部分的にヘレニズム 期のパロドスの壁の部材を再利用していることがわかった。また、 遺構の現状から各周回通路へ別々の出入口が設けられていたことが 判明している。これは、傾斜地に建設された劇場としては一般的で、 アテネのディオニソス劇場やエピダウロスの劇場にも見られる ${ }^{18)}$ 。

客席勾配に関しては、現状で残る客席西中腹の石材列などの遺構 の位置座標から復元した客席勾配が 21.78 度、階段通路やパロドス 壁の壁部材上面と笠木部材接合面の傾斜から予想される客席勾配が およそ $21 〜 22$ 度であったことから、前稿の問題点であった出土部 材の勾配と座席の復元勾配との矛盾が解消された。客席勾配 21 22 度という值は、野口・渡邊氏が劇場の建設年代別に客席勾配を算出 した結果、ギリシア時代は平均 26.0 度、ヘレニズム時代は平均 26.9 度、ローマ帝政期は平均 28.6 度としているが、これらと比較すると かなり緩やかである ${ }^{19}$ 。その要因として、メッセネの劇場が建てら れた斜面の傾斜が緩やかであったことが考えられる。そして、おそ らくローマ劇場に改築する際にも、少なくとも第 1 層は勾配の変更 をしなかった可能性が高い。

今後の課題は、劇場建物各部の年代検証をおこなうことであるが、 これはテメリス氏による発掘結果の発表を待つ必要があるだろう。 


\section{謝辞}

本研究は、平成 $21 \sim 24$ 年度日本学術振興科学研究費基盤 $(S)$ 課題 番号：20226012) (研究代表者 : 伊藤重剛) の助成を得た。記して謝 意を表する。

注

1）メッセネの遺跡は、19 世紀末から 20 世紀前半にかけて、Th.ソフリス氏、G. オイコノモス氏により発掘が扢なおれた。その後、1957 年から 1974 年に かけて、考古学者のオルランドス氏の指揮下で長期にわたる発掘が执こな われたが、最終的な発掘報告書は発行されていない。それ以降しばらくは 発掘がおこなわれていなかったが、1987 年からメッセネ考古学協会による 大規模な発掘が開始され、スタディオン、アスクレピウス神域、劇場、ア ゴラなどの大規模な公共施設の遺構が出土しており、現在も継続して調査

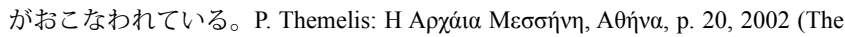
Ancient Messene in Greece), Th. Sophoulis: Prakt, p. 27, 1895; AM, p. 375, 1895; AA, p. 73, pp. 453-454, 1896 G. Oikonomos: Prakt, pp. 201-205, 1909; pp. 55-66, 1925; BCH, pp. 453-454, 1925, A. K. Orlandos: Report of Excavation , Ergon, pp. 143-148; 1960, pp. 110-117; 1961, 159-166; 1963, pp. 119-125; 1964, pp. 88-102, 1959; pp. 90-101, 1965; pp. 97-132, 1970; pp. 67-81, 1973; pp. 79-82, 1974

2）劇場の発掘報告は、以下の年報を参照。P. Themelis: Prakt, pp. 73-79, Eiк.

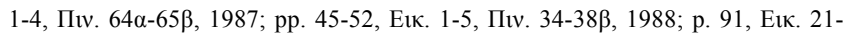

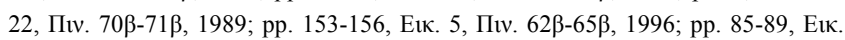

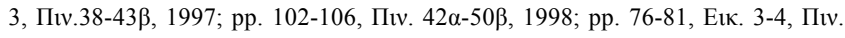

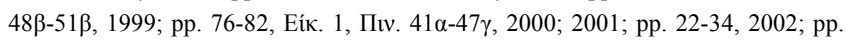
26-28, 2003; pp. 28-29, 2004; pp. 39-48, 2005; pp. 32-43, 2006

3）熊本大学によるメッセネの劇場の調査報告は、以下の通り。大塚和樹, 伊 藤重剛, 吉武隆一, 岩田千穂 : 地中海古代都市の研究 (136) 古代都市メッセネ における劇場の客席の復元に関する研究, 日本建築学会研九州支部研究報告, 51 号 3, pp.769-772, 2012 年 3 月; 吉武隆一, 伊藤重剛, 岩田千穗: 地中海古代 都市の研究 (133) メッセネにおける劇場調査報告 2010(1) スカエナエ・フロ ンスの柱頭, 日本建築学会研九州支部研究報告, 50 号 3, pp.637-640, 2011 年 3 月; 岩田千穂, 吉武隆一, 伊藤重剛 : 地中海古代都市の研究 (134) メッセネ における劇場調査報告 2010(2) ローマ時代スケーネの復元試案, 日本建築学 会九州支部研究報告, 50 号 3,pp.641-644, 2011 年 3 月; 吉武隆一, 伊藤重剛, 岩田千穂ほか: 地中海古代都市の研究 (128) メッセネにおける劇場調査報告 2009(1) 平面, 日本建築学会九州支部研究報告, 第 49 号 3(計画系), pp.585588, 2010 年 3 月; ソクンティー・セイン, 吉武隆一, 伊藤重剛, 岩田千穂ほか : 中海古代都市の研究 (129) メッセネにおける劇場調査報告 2009(2) スケーネ, 日本建築学会九州支部研究報告, 第 49 号 3 (計画系), pp.589-592, 2010 年 3 月; 岩田千穂, 伊藤重剛, 吉武隆一ほか : 地中海古代都市の研究 (130) メッセネに おける劇場調査報告 2009(3) スケーネ部材, 日本建築学会九州支部研究報告, 第 49 号 3(計画系), pp.593-596, 2010 年 3 月; 谷晧司, 伊藤重剛ほか : 地中海 古代都市の研究 (123) 古代都市メッセネにおける劇場調査報告 2008(1) 概要, 日本建築学会九州支部研究報告, 第 48 号 (計画系), pp.773-776, 2009 年 3 月; 中之丸諭志, 伊藤重剛ほか : 地中海古代都市の研究 (124) 古代都市メッセに 扔ける劇場調查報告 2008(2) 出土部材, 日本建築学会九州支部研究報告, 第 48 号 (計画系), pp.777-780, 2009 年 3 月

4）エピダウロスの劇場は、現状分析をもとに、平面、断面から詳細に至るま で、精緻に復元が扔こなわれている。Gerkan, Armin von and Mueller-Wiener, Wolfgang: Das Theater von Epidauros, Stuttgart, 1961

5）客席部の各部名称については、以下のと抢りとする。客席はいわゆる cavea の部分、座席はその内の一段分を指す。エウリポスは、オルケストラ の外縁に沿って設けられた溝である。客席の円弧に沿って水平に回る通路 を周回通路、上下に移動するために客席内に設けられた階段を階段通路と する。周回通路は、ギリシア劇場において diazoma、ローマ劇場において praecinctio と呼ばれる。客席のうち、周回通路と階段通路とに挟まれた楔型 の一角を、クネイ cunei と呼ぶ。パロドスの壁は、一般に analemmata と呼 ばれる部分で、客席の端部を支え、同時にパロドスに面する壁となる。

6）劇場の発掘成果をまとめた中間報告書は以下の通り。P. Themelis: To Apxáı

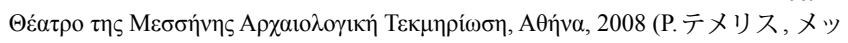
セネの劇場の考古学的検証).

7）テメリス氏は、メッセネの劇場のローマ時代の舞台建物は後 $2 \sim 3$ 世紀に 建設されたとしているが、吉武氏により舞台建物のスカエナエ・フロンス に使用された部材の建築装飾の様式分析が抽なわれたところ、後 1 世紀 の特徵を備えていることなどから、舞台建物の建設は後 1 世紀におこなわ れたことが明らかになった。吉武隆一: 古代都市メッセネの劇場のスカエナ
エ・フロンスにおける建築装飾の様式分析および建設年代, 日本建築学会計 画系論文集,第 78 巻,第 684 号,pp. 485-495, 2013 年 2 月

8）岩田千穂,吉武隆一, 伊藤重剛 : ギリシア古代都市メッセネにおける劇場の ローマ時代舞台建物の復元試案, 日本建築学会計画系論文集, 第 77 巻第 678 号, pp.1967-1976, 2012 年 8 月; 吉武隆一: 古代都市メッセネの劇場における スカエナエ・フロンスの新たな復元案, 日本建築学会計画系論文集, 第 78 巻, 第 691 号,pp. 2055-2065, 2013 年 9 月

9）大塚和樹, 伊藤重剛, 吉武隆一, 岩田千穂: 前掲書, pp.769-772, 2012 年 3 月 10）シアー氏は、多色彩大理石板によるオルケストラ床面の舗装は、アウグス トゥス帝の頃からはじまったとしている。また、オプス・セクティル (opus sectile)によるオルケストラの舗装はアテネのディオニソス劇場でネロ帝の 頃 (後 54-58)、コリントの劇場でハドリアヌス帝の頃 (後 117-138) におこな われている。F. Sear: Roman Theatres, Oxford, pp.80-81, 2006

11）本稿では、エウリポス外縁の円弧を延長した円の中心を、オルケストラの 中心としている。10 本の階段通路のうち西にある 2 本の延長線がオルケス トラの中心に一致しないことは、これらの階段通路が造られた年代が、他 の 8 本が造られた年代と異なる可能性を示唆する。

12) ディルケ氏は、座席を部材構成により分類した。石造の座席は、一般型と 節約型に分けられる。一般型は、座面と足置きが単一部材で作られるもので、 エピダウロスの劇場で見ることができる。節約型は、一般型をもとに複数の 部材を組み合せることにより構成するものである。ディルケ氏は、節約型 をさらにアルゴス型、デロス型、エレトリア型、メガロポリス型に細分し ている。O.A.W. Dilke: The Greek Theatre Cavea, BSA, No. 43, pp. 153-162, 1948 13）メッセネのエクレシアステリオンは、前 2 世紀半ば以前に建てられたと

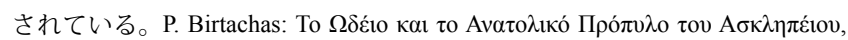
pp. 93-94, 2008. メッセネで座席を有する遺構は劇場のほかにスタディオンと アスクレピオス神域のエクレシアステリオンとがある。スタディオンの座席

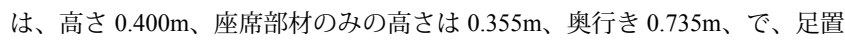
きが座面よりも $0.095 \mathrm{~m}$ 低くなっている。また、エクレシアステリオンの座 席は、高さ $0.340 \mathrm{~m}$ 、座席部材のみの高さ $0.360 \mathrm{~m}$ 、奥行き $0.680 \mathrm{~m}$ で、足置

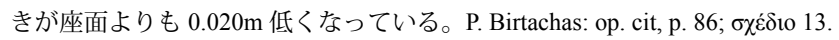

14）アルゴスの劇場の上部周回通路が幅 $1.98 \mathrm{~m}$ 、壁の高さ $1.35 \mathrm{~m}$ 、エピダウロ スの劇場の周回通路が幅 $1.9 \sim 2.0 \mathrm{~m}$ 、壁の高さ $1.38 \mathrm{~m} 、$ デロスの劇場の周 回通路が幅 $1.5 \mathrm{~m}$ 、壁の高さ $1.17 \mathrm{~m}$ である。Gerkan, Armin von and MuellerWiener, Wolfgang:op. cit, tafel 9, 1961; O. W. Dilke: Details and Chronology of Greek Theatre Caveas, BSA, No. 45, pp. 40-44, 1950

15）石灰岩材列が下部周回通路床面の仕上げ材であった場合、下部周回通路 の後端がオルケストラ中心からの水平距離 $33.710 \mathrm{~m}$ の位置にあり、通路前面 は、座席幅 $0.350 \mathrm{~m}$ と通路幅 $1.830 \mathrm{~m}$ を引き、オルケストラ中心から $31.88 \mathrm{~m}$ の位置にあったということになる。これは、西パロドスの途中にある床の ような石灰岩列の位置（オルケストラ中心から 31.76 35.25m）とは近いが、 東後壁南端部の斜路が北へ折れ曲がる部分の位置 (オルケストラ中心からの 水平距離 33.45 38.49m) と約 $2 \mathrm{~m}$ ずれるため、石灰岩材列が下部周回通路の 仕上げ部材であったとは考えにくい。

16）野口・渡邊氏によると、客席の傾斜はローマ帝政期の劇場 80 例で平均 28.6 度である。野口力, 渡邊道治 : ギリシア・ローマ劇場の客席に関する特 徵について, 日本建築学会九州支部研究報告 50 号 3,pp.609-612, 2011 年 3 月

17）野口・渡邊氏は、客席の上下層間のクネイ数の関係を分析しており、3 層 構成の劇場において客席第 2 層のクネイ数が第 1 層のクネイ数と同数となる ものが 11 例、第 3 層のクネイ数が第 2 層のクネイ数の 2 倍となるものが 5 例存在するとしている。野口力, 渡邊道治 : ギリシア・ローマ劇場の客席の 階段状通路の配置について, 日本建築学会九州支部研究報告 51 号 3, pp.781784, 2012 年 3 月

18) エピダウロスやメガロポリスの劇場では、同じように、外部から直接下部 周回通路へ出入りすることができる。E. A. Gardner, W. Loring, G. C. Richards, W. J. Woodhouse: The Theatre at Megalopolis, JSH, 11, pp. 294-298, 1890; Armin von and Mueller-Wiener, Wolfgang: op. cit, tafel 9

19) 野口力, 渡邊道治 : 前掲論文, pp.609-612

図版出典

写真 1 メッセ不考古学協会撮影

写真 2,4,5 伊藤撮影

写真 3 岩田撮影

図1 メッセ不考古学協会作成

図 2 7 熊本大学ギリシア古代建築調査団作成

図 8 10 岩田作成 